\title{
legelivet
}

På disse sidene i Tidsskriftet - legelivet - finner du stoff om legers liv.

Her er det presentasjon av arbeidssteder, nyhetssaker, nye doktorgrader,

nye spesialister og minneord. Alt samlet på ett sted - så du kan følge enda bedre med.

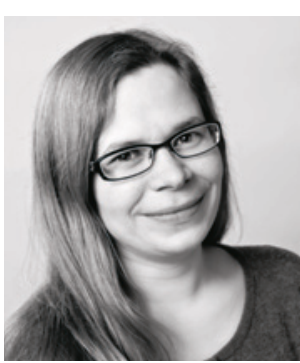

Kristin Viste. Foto: Einar Nilsen

Kristin Viste er ph.d i cellulær biokjemi. Hun er under spesialisering i medisinsk biokjemi.

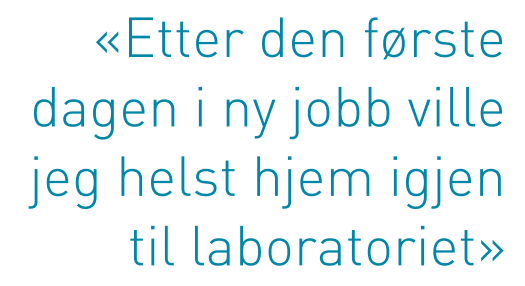

til laboratoriet»

\section{With a little help from my friends}

\author{
Overgangen fra laboratorielivet til klinisk arbeid har vært brå, men det \\ meste løser seg med gode kolleger.
}

Mange spesialiteter krever sideutdanning. Vi som vil bli spesialister i medisinsk biokjemi må ha et år i klinisk tjeneste, og vi kan velge ganske vidt innen de større kliniske spesialitetene. Jeg ville bli på sykehuset og var heldig som fikk jobb på en avdeling som var relevant for senere laboratoriejobb.

Etter fire år uten pasientrettet arbeid var det med skrekkblandet fryd jeg vendte tilbake til pasientene. Hverdagen i et laboratorium er på den ene siden veldig selvstendig og fri, samtidig som det ligger skriftlige prosedyrer, opplæring og sertifisering i grunn for mye av arbeidet. Det er alltid travelt, men oftest i form av at det ligger store oppgaver som må løses over litt tid. Legen står ganske fritt til å prioritere mellom disse oppgavene i det daglige. I overgangen til klinisk arbeid var jeg klar over at oppgavene i mye større grad ville styre dagen min enn omvendt.

Jeg var imidlertid ikke forberedt på hvor travelt klinisk arbeid ville være. Etter den første dagen i ny jobb ville jeg helst hjem igjen til laboratoriet. Etter først å ha fått en omvisning på avdelingen ble jeg satt til å ta imot pasienter. Siden jeg er blitt vant med obligatorisk opplæring og sertifisering etter skriftlige prosedyrer var dette litt uventet. Mange andre helseprofesjoner har en opplæringsperiode hvor de jobber tett sammen med erfarne kolleger i flere uker. Noen avdelinger gir også legene dette, men jeg har inntrykk av at tankegangen mange steder er «du er jo lege, mye av legejobben kan du spør om du lurer på noe». Stakkars de mer erfarne legene, for jeg har mast og gravd til de uskrevne prosedyrene ble innarbeidet. I tillegg har jeg fått en gjennomgang av de sentrale skriftlige prosedyrene etter hvert, bare ikke den første dagen.

Min første dag på jobb var i tillegg den travleste som hadde vært på flere måneder med hensyn til antall nye pasienter. 15 pasienter kom og skulle skrives inn av meg og en litt mer erfaren lege. Vi så raskt at det ikke gikk. En liten telefon, og det føltes som om LIS-kollegene strømmet til for å hjelpe dersom de klarte å få frigitt litt tid. Sammen fikk vi håndtert arbeidet. Jeg har opplevd at mestringen kommer etter hvert - selv uten strukturerte opplæringsplaner. Hverdagen fungerer imidlertid bare fordi det er en gjeng leger som hjelper hverandre slik at hjulene går rundt. Jeg tar meg stadig i å gå rundt og synge på en enkeltstrofe fra en gammel Beatles-sang: Oh, I get by with a little help from my friends.

\section{Kristin Viste}

kristin.viste@helse-bergen.no 